\title{
DISCUSSION OF THE LEVY AND MELTZER PAPERS
}

\section{William Poole}

Michael Levy has assumed the task of explaining the persistence of inflation. I confess, though, that I got off to a bad start at the very beginning of his paper. His second sentence reads: "Monetarist explanations of this deep-seated inflation provide no insights as to its economic, social, and political causes" (emphasis added). And a sentence towards the end of his summary reads: "Fiscal and monetary policy restraint will be necessary, but may not be sufficient [to control inflation]." Fortunately, however, Levy does not really believe these claims. On page two of his paper he says that, "on a purely technical level, the monetarists have, of course, all the answers. In fact, some of my own econometric exercises have tended to reconfirm their valuable, if somewhat simplistic, generalizations."

If we strip away the loaded words such as "simplistic," then it is clear that Levy accepts the basic argument that inflation cannot occur in the absence of excessive money growth. Accepting this proposition, Levy surely does not believe that successfut control of inflation would be possible without slowing money growth. Indeed, I cannot believe that Levy would claim that slowing money growth would fail to reduce inflation. He simply does not in fact believe that monetarist explanations provide no insight into the economics of inflation.

Dr. Poole is Professor of Economics at Brown University. 
Levy's paper is not about monetarist propositions linking money growth to inflation, but about the causes of excessive money growth. This issue is obviously important. But the reasons monetarists have not paid much attention to this issue to date are, first that it was important to gain agreement that inflation is indeed a monetary phenomenon -- a proposition not widely accepted thirty years ago -- and, second, that the methods of economic analysis may not provide great insight into the causes of excessive money growth. Levy feels that the important issues concern changes in the economic and social structure that have produced an infutionary environment.

Before commenting further let me introduce a qualification to the simple monetarist view. Clearly, insofar as changes in the economic and social structure, in the average tax rate, and in the regulatory burden affect incentives and productivity, the rate of productivity growth may 510 down. Reduction in the growth of real output, given the rate of money growth, will raise the rate of inflation. As a first approximation, what matters is the money stock per unit of real GNP. But the slow-down in productivity growth and therefore in output growth can directly account for only a very small part of our inflation. We might be able to explain one to two percentage points of the inflation in recent years by the slow-down in output growth. But that is not what all the shouting is about. If the current rate of inflation were only one or two percentage points above the rate of the early sixties, then the subject of this conference would not be inflation but rather productivity or some other issue.

If I understand Levy correctly, he feels that sociological and non-monetary factors have accelerated the rate of inflation and that 
the monetary authorities have been dragged along -- forced to accommodate with money growth the more fundamental factors producing inflation. Even on this view, however, Levy should be much more interested than he is in what he calls the simplistic monetarist explanation.

If the price level were very closely linked to the money stock, with a very small margin of error, then it would be absolutely clear that non-monetary factors could work to increase inflation only insofar as they operated quite directly on the Federal Reserve. The greater the amount of slack or imprecision in the money/price relation, the more credible Levy's argument becomes. If the relation is imprecise, especially in the short run, there is much room for non-monetary factors to produce an acceleration in the rate of inflation directly, and for the Federal Reserve to be drawn into monetary expansion later by pressures to sustain the ongoing inflation process. The very word "acm commodation" has the flavor of the central bank responding to an inflation that has a ready occurred in order to prevent longer-run forces from reversing the inflation through a process involving unemployment. Levy presents data showing changes in defense spending, government transfers, and so forth. But he presents no evidence whatsoever that even bears on the validity of his claim that factors such as these are responsible for the inflation. Surely time series evidence on United States inflation relative to goverment spending would be relevant. Also, cross section evidence relating the rate of inflation to the size of the government budget or its rate of growth in different countries would be relevant. Does Levy dispute the common finding that inflation follows rather than leads money growth, a finding that seems inconsistent with the accommodation argument? 
Since Levy has presented no evidence, I'm forced to make a few coments based on casual empiricism and a priori plausibility. One of Levy's claims is that the erosion in the growth of real incomes has led workers and firms to seek higher wages and prices in an attempt to recoup their lost income growth. If this argument is true, why did wages and prices fall sharply as people became poorer between 1929 and 1933 ? Is the short-run Phillips curve -- which shows that wage inflation slows as people become poorer through unemployment - - consistent with Levy's proposition? If growth in taxes has been a major factor in reducing growth in disposable income, then why have we not seen more activity to reduce government spending and taxes rather than the activity claimed by Levy to raise nominal wages and prices? I may be wrong, but proposition 13 pressures seem awfully weak to me at the faderal level, and in any event seem to be a lagged result of the inflation process rather than part of a process that can explain the inflation.

What other evidence beside nominal wage and price increases can we look at? What about strike activity, or union membership, or concentration ratios in industry? All of these would seem to have some possible connection to inflation, or at least as symptoms of the process Levy is talking about. My impression is that these factors all cut in the wrong direction in the United States. Most fundamentally, how can real factors, other than through productivity effects and effects on Federal Reserve behavior, have anything to do with nominal magnitudes?

Levy seems to recognize the importance of explaining Federal Reserve behavior; his footnote on page seventeen deals at some length 
with the question of the role of budget deficits in explaining Federal Reserve money creation.

I believe that a number of factors, some of which are closely connected to the ones Levy has emphasized, should be examined in terms of their effect on Federal Reserve behavior. My 1 ist of important items is this:

1. Since the mid-sixties there have been consistent underestimates of the natural rate of unemployment by the Federal Reserve and by the economics profession. These underestimates have led to money growth that on average has been too high, even accepting the view that monetary policy should aim for an unemployment rate close to the natural rate.

2. There has been a great over-emphasis on nominal interest rates and a view that short-run money growth doesn't really matter. Although the Federal Reserve has long recognized the importance of long-run money growth, it always seems to be operating in a series of short runs that never add up to a long run.

3. The Federal Reserve has from time to time made political miscalculations based on a combination of overly optimistic forecasts of the effectiveness of fiscal actions and overly optimistic forecasts of when fiscal actions would occur. Probably the best example of this point is the Fed's delay in tightening money in 1967 while waiting for Congress to pass a tax increase.

4. The Federal Reserve's policy horizon has been too short, Ordinari1y, the Fed looks ahead long enough to see significant impacts of monetary policy on employment and output but not long enough to see any important impact on prices. 
5. The Federal Reserve has used a poor control mechanism based on the federal funds rate. This mechanism has produced a procyclical monetary policy because it makes persistent procyclical mistakes so easy.

6. The Federal Reserve is obviously responsive to political pressures, especially from the administration. These political considerations may have reflected concern, from time to time, over reelection of a President and over reappointment of a Federal Reserve Board Chairman. I continue to believe that Federal Reserve behavior is not at all a simple function of broad societal trends. Accidents of history such as assassinations do happen and are important. While I certainly would not rule out the importance of research on generat principles of political behavior, I still feel that neglecting the interplay of personalities and events is a mistake. In an endeavor of this type, traditional historical analysis can provide very substantial insights.

In summary, I believe that Levy provides a misleading interpretation of what monetarism is all about. Monetarism involves the economics of the relations between money, output, prices, and interest rates, and the economic processes responsible for these relations. It does not pretend to offer an economic explanation of money growth and should not, therefore, be criticized for not doing so. Now that monetarist propositions -- at least in their long-run form -- are so widely accepted, it clearly makes sense to move on to issues concerning why the monetary authorities behave the way they do. Levy has offered a number of interesting hypotheses on this question, but has not provided any evidence. To my taste, his approach is less 
productive than it might be because he pays so little attention to the monetary authority itself. Surely the Federal Reserve should be the focal point of the political and sociological analysis. The Fed has far more than a caretaker function. If the factors Levy discusses are important, we need to know how they impinge on the Federal Reserve in order to have much confidence in the argument.

Now let me turn to the paper by Allan Meltzer. I will start with an outline of his argument as I understand it.

First, Meltzer believes that expectationa? errors affect output. The expectational errors that he stresses are those between the normal, or permanent plus the transitory components. He mentions in passing that this view is different from that of Lucas. While it is true that Lucas uses a spatia rather than a temporal model, I think that it really comes to much the same thing. Additional output can be obtained in the Lucas model only if labor is willing to substitute hours intertemporarily.

In any event, the Meltzer view is that when prices are viewed as temporarily high the level of output is expanded, and when prices are temporarily low the level of output is contracted. Actually, it is probably better for me to state Meltzer's proposition a bit differentIy: the permanent level of prices depends on the permanent level of the money stock and it is deviations of the actual money stock from the permanent level that are most clearly related to deviations of output from normal fu11 employment output.

Since deviations of output from potential output are related to expectational errors, it is important to investigate the formation of these expectations. To i]lustrate the basic idea, Meltzer uses a 
simple model from the statistics literature in which a time series has known properties consisting of permanent and transitory variations. The inference problem is to use the past data to make the best guess as to the permanent component in the next period. The solution to the problem requires knowledge of the permanent and transitory variances. Given that information, the next-period forecast depends on a distributed lag of the past observations of the series, with the distributed lag weights depending on the permanent and transitory variances. This basic idea can be generalized easily -- although the technical problems may not be solved easily -- by considering more complicated time series models including multivariate frameworks. However, the basic idea comes through quite clearly in the univariate model analyzed by Meltzer. His tables 1 and 2 provide the flavor of how the means and permanent and transitory variances might be extracted from the data for different periods.

Now let me make an important distinction that does not seem very clear in Meltzer's paper. When we examine a policy of gradualism there are two analytically distinct considerations. One concerns the time series of agents' forecasts of permanent values and the magnitudes of expectational errors under the assumption that agents' estimates of the permanent and transitory variances remain fixed and given an assumed money growth path. Here, it is clear that if money growth slows sharp$1 y$, then the market will interpret the initial slow-down as being largely transitory; if the slow-down is in fact permanent, then there will be a large and persistent expectational error. Under these assumptions, the case for gradualism is compelling. Only with a gradual 
decline in money growth would it be possible to avoid large expectational errors and the accompanying losses in output.

An entirely separate issue -- and one that I think is at the heart of the problem -- concerns the way in which agents change their estimates of the permanent and transitory variances over time. Meltzer's discussion is much less helpful on this issue. If the Federal Reserve could convince agents that the money growth process had changed and could convince agents that it would slow money growth sharply, then forecasts of the permanent money stock would not be determined by the old distributed lag on past observations. Under these assumptions, the fed could slow money growth abruptly without producing expectational errors and there would be no case for gradualism.

Meltzer has not offered any formal analysis of how agents learn from experience to change their estimates of the permanent and transitory variances. Nor has Meltzer offered an analysis of how agents might be led to change their estimates of these variances by the Fed introducing a new policy, a process which would not require any learning from past money stock observations at all. My comment on this point is not meant to reflect a criticism of Meltzer's paper; I do not know of any interesting models of learning and I do not have the foggiest idea of how to go about modeling this process. My point is simply that it is important to separate the issue of calculating permanent values given estimates of the variances from the issue of how agents form new estimates of these variances over time.

The only constructive thought I can offer is that prescriptions as to the best path for the money stock in the future might be based in part on an analysis of the effects of reducing transitory variance. 
Money growth has been high in the recent past; if the actual rate of money growth is brought down only slowly from this high initial starting point and if the transitory variance is compressed by making this slow-down smooth and in accordance with announced intentions, then it is possible that the initial effects would actually be to raise agents'estimates of the permanent rate of money growth for the next few periods. This result would occur if a significant part of the recent high money growth had been regarded by agents as transitory and therem fore had not been built into their estimates of the permanent part of maney growth. The likelihood of the perverse result could be investigated by examining the effect of a reduced transitory variance on money growth expectations for next year in a time series model applied to actual money growth over the past few years.

I have two final comments. First, as John Taylor has emphasized, there is considerable uncertainty about the relative validity of purely expectational theories of the business cycle and theories that stress lagged adjustment due to contracts and similar types of institutions. As Meltzer has noted but not emphasized, the case for gradual reduction of money growth is considerably strengthened by this uncertainty because insofar as the contract view has validity, a sharp reduction in money growth -- even if fully anticipated -- would produce a sharp decline in output.

Secondly, although we have concentrated on economic factors, 1 think it is worth mentioning political processes. It is not obvious to me that maintainance over a long period of time of a gradual reduction of the money stock is politically feasible. It is certainly conceivable that a quick and dirty reduction of money growth, accepting the 
severe output effects that would occur, is the only solution that is politically viable. I am not sure whether or not I believe that a quick purging of inflation would be better politically, and even if I did know what I believe I would not have any idea of why I believed it. Nevertheless, this issue is surely important for a full policy analysis of winding down inflation. An economic andysis of the rinimum cost method of reducing inflation is obviousty important, but unfortunately it is not at a 11 clear that the cost-benefit calculation that governs the political process is very closely connected to the economic costs and benefits, however fimly we may establish then. 